\title{
The Most Influential Publications on Endoscopic Submucosal Dissection: A Bibliometric Analysis
}

\author{
Chang Seok Bang ${ }^{1,2,3}$, Jae Jun Lee ${ }^{3,4}$, Gwang Ho Baik ${ }^{1,2}$ \\ Department of Internal Medicine, Hallym University College of Medicine ${ }^{1}$, Institute for Liver and Digestive Diseases, Hallym University ${ }^{2}$, \\ Institute of New Frontier Research, Hallym University College of Medicine, Department of Anesthesiology and Pain Medicine, Hallym \\ University College of Medicine ${ }^{4}$, Chuncheon, Korea
} Background/Aims: Endoscopic submucosal dissection (ESD) is the first-line treatment for superficial gastrointestinal neoplasms
with negligible lymph node metastasis. It has evolved through improvements in expertise and equipment, increased understanding
of indications and short- and long-term outcomes, and better management of complications. This study aimed to assess and charac-
terize the most influential publications in ESD research.
Materials and Methods: We searched the top 50 most cited articles using Web of Science Core Collection (WoSCC) and Google
Scholar (GS) from the inception of these services to January 2019. The top 50 Altmetric Attention Score (AAS) articles based on
online media mentions were also searched. Each article was evaluated for the number of citations, title, journal, and publication
year.
Results: The number of citations for the top 50 WoSCC articles on ESD ranged from 37 to 199; Endoscopy published the most ar-
ticles (20\%). Among the top 50 GS articles, Gastrointestinal Endoscopy published the most ESD articles (34\%) and the most
shared AAS articles (42.6\%). PubMed Central article citations in WoSCC or GS showed significant correlation with those from
each metric, unlike AAS. The words with the highest relevance scores were "submucosal tunnel dissection," "guideline," "novel
submucosal gel," "adhesive material," "cell sheet," "esophageal ulcer," "hemospray," and "endoscopic closure," while the follow-
ing words were influential: "meta-analysis," "esophageal stricture," "perforation," "bleeding," "fibrin glue," "artificial ulcer,"
"porcine model" and "esophageal squamous cell neoplasia," excluding "ESD."
Conclusions: This study presents a detailed list of influential articles, journals, and topic words. (Korean J Helicobacter Up Gastrointest Res 2020;20:306-317)

Key Words: Bibliometrics; Endoscopic submucosal dissection; Publications; Research

\section{INTRODUCTION}

Academic impact of publication is frequently reflected by the number of times the publication is included as a citation. ${ }^{1}$ As the amount of newly published literature that researchers need to be aware of increases and the importance of selective searching and summarization grows, the meaning of citation counts as a bibliometric index is growing. Many milestones of literature have dramatically influenced the promotion of specific research fields, and there are many cases in which the impact of older publications does not diminish. However, there has been little work in the identification of influential literature in the

Received: August 3, 2020 Accepted: August 28, 2020

Corresponding author: Chang Seok Bang

Department of Internal Medicine, Hallym University College of Medicine, Sakju-ro 77, Chuncheon 24253, Korea

Tel: +82-33-240-5821, Fax: +82-33-241-8064, E-mail: csbang@hallym.ac.kr field of gastroenterology.

Citation counts have been the most widely adopted and useful method for measuring the impact of research activity. However, it has been criticized because the citation only occurs for a certain amount of time after publication, leaving influential literature uncited in many cases. It is also impossible to recognize the reasons the literature is cited, whether to express support or to criticize the content of the text. Moreover, solely examining citation frequency is inadequate to measure the impact beyond the particular academic field.

Social media influence in medicine is growing. ${ }^{2}$ The current production of knowledge and distribution of data is frequently mediated by social media in the form of unstructured text data, rather than the traditional journal form. ${ }^{3}$ Medical knowledge is no longer only limited to experts and is accessible for patients to share and disseminate. With the widespread use of social media, a new concept of social web-based

Copyright $\odot 2020$ Korean College of Helicobacter and Upper Gastrointestinal Research

(a) The Korean Journal of Helicobacter and Upper Gastrointestinal Research is an Open-Access Journal. All articles are distributed under the terms of the Creative Commons Attribution Non-Commercial License (http:// creativecommons.org/licenses/by-nc/4.0) which permits unrestricted non-commercial use, distribution, and reproduction in any medium, provided the original work is properly cited. 
metrics ('altmetrics') has been implemented as an indicator that more quickly reflects influence and attention than traditional indicators. ${ }^{4}$ Altmetric Attention Score (AAS) accounts for the scientific and social impact of an article after publication and is based on the weighted count of 'mentions' of an article across various online sources while reflecting the relative reach of each type of source. ${ }^{4,5}$

Endoscopic submucosal dissection (ESD) is the established treatment for superficial gastrointestinal neoplasms with minimal risk of lymph node metastasis. The most important advantage of this procedure was in achieving curative resection with minimal invasiveness, avoiding invasive surgery that inevitably accompanies substantial morbidity. It has emerged and evolved through an improvement of skills, expertise, and equipment, to arrive at a better understanding of indications, short- and long-term outcomes, and management of complications. This study aimed to assess and characterize the most influential publications in ESD research.

\section{MATERIALS AND METHODS}

\section{Selection of bibliometric tools}

To conduct a citation analysis in the field of ESD research, we selected the following three representative bibliometric tools: Web of Science Core Collection (WoSCC; Clarivate Analytics, Philadelphia, PA, USA), Google Scholar (GS; Google LLC., Mountain View, CA, USA), and Altmetric Explorer (Altmetric LLP, London, UK).

The WoSCC is an online scientific indexing platform that provides a comprehensive citation searching mechanism for their collection of high-quality scholarly content, providing access to multiple databases for research discovery, covering multidisciplinary content, ${ }^{6}$ which allows for an in-depth exploration of specialized academic fields. The WoSCC search of the top 50 most-cited articles was able to retrieve articles published from 2013 to 2017 and included relatively recent citations from high-quality journals that have been integrated annually from Journal Citation Reports (JCR) (timespan option of searching was set for all years).

GS is an online search engine that indexes publications from academic and scientific web domains. It provides bibliographic references and citations from most peer-reviewed online academic journals, books, conference papers, theses, dissertations, preprints, and court opinions and patents. ${ }^{7}$ GS has indexed approximately 389 million documents, making it the world's largest academic search engine as of January 2018. Researchers can also obtain information from non-JCR journals. ${ }^{9}$ Harzing's Publish or Perish software is a third party tool for calculating numbers of citations that could retrieve articles published from 1999 to 2015, pulling citations from various sources, not limited to JCR journals and recent research. ${ }^{10}$

Altmetric.com provides real-time online mentions of published articles from public policy documents, mainstream media, online reference managers, post-publication peer-review platforms, Wikipedia, Open Syllabus Project, patents, blogs, research highlights from F1000Prime, and social media platforms, including Facebook, Twitter, and YouTube, from 2011. It provides AAS to measure the overall level of online impact using Altmetric Explorer. ${ }^{4}$

PubMed is the most widely used tool for searching medical literature. Since it does not provide a tool for analysing the citation counts by bibliometric index, it was used to validate the citation counts of WoSCC and GS.

\section{Identification of the top 50 most-cited articles and the top 50 most-mentioned AAS articles in online media}

We searched the top 50 most-cited articles using the WoSCC and GS from the inception of these services to January 2019 with two independent evaluators (YJY and CSB). The search term was 'endoscopic submucosal dissection'. The site was accessed on 1 February 2019 to avoid changes in the online activity of publications. Articles with the same number of citation counts were included in the analysis even if the number of enrolled articles exceeded 50. Then, we performed a comparison of the citation counts for the top 50 articles from WoSCC and GS with those of PubMed Central (PMC), using the PubMed platform on the same day. Since the publication dates of the GS top 50 most-cited articles ranged from 1999 to 2015, it was difficult to reflect recent citations. 
Therefore, the top 50 articles published after 2015 among the top 1,000 most-cited articles according to GS bibliometrics were extracted and analysed separately. AAS was also accessed and retrieved on 1 February 2019 using the 'advanced search' function in Altmetric Explorer.

All articles were retrieved and ranked in descending order based on the citation counts obtained by WoSCC, GS, and AAS. The titles and abstracts of all identified ar- ticles were reviewed to exclude irrelevant publications. Publications relevant to ESD, such as endoscopic mucosal resection (EMR), peroral endoscopic myotomy (POEM), or submucosal tunnel dissection, were included. Full-text reviews were conducted for cases where it was impossible to determine the relevance of ESD research. Disagreements between the evaluators were resolved by discussion.

Table 1. The Top 10 Most-cited Articles of WoSCC Bibliometrics in ESD Research (2013 2017)

\begin{tabular}{|c|c|c|c|c|c|c|c|}
\hline Rank & $\begin{array}{l}\text { First } \\
\text { author }\end{array}$ & Journal & Title & $\begin{array}{l}\text { Citation } \\
\text { counts } \\
\text { (WoSCC) }\end{array}$ & $\begin{array}{l}\text { Citation } \\
\text { counts } \\
\text { (PMC) }\end{array}$ & $\begin{array}{l}\text { Stomach vs. } \\
\text { colon vs. } \\
\text { esophagus } \\
\text { vs. } \\
\text { duodenum }\end{array}$ & Type of article \\
\hline 1 & $\begin{array}{r}\text { Pimentel- } \\
\text { Nunes P }\end{array}$ & $\begin{array}{l}\text { Endoscopy } \\
2015 ; 47: 829-854\end{array}$ & $\begin{array}{l}\text { Endoscopic submucosal dissection: } \\
\text { European Society of Gastrointestinal } \\
\text { Endoscopy (ESGE) guideline }\end{array}$ & 199 & 78 & All & $\begin{array}{l}\text { Guideline/consensus } \\
\text { report }\end{array}$ \\
\hline 2 & Tanaka S & $\begin{array}{l}\text { Dig Endosc } \\
\text { 2015;27:417-434 }\end{array}$ & $\begin{array}{l}\text { JGES guidelines for colorectal } \\
\text { endoscopic submucosal } \\
\text { dissection/endoscopic mucosal } \\
\text { resection }\end{array}$ & 140 & 48 & Colon & $\begin{array}{l}\text { Guideline/consensus } \\
\text { report }\end{array}$ \\
\hline 3 & Toyonaga $\mathrm{T}$ & $\begin{array}{l}\text { Surg Endosc } \\
\text { 2013;27:1000-1008 }\end{array}$ & $\begin{array}{l}\text { 1,635 Endoscopic submucosal } \\
\text { dissection cases in the esophagus, } \\
\text { stomach, and colorectum: } \\
\text { complication rates and long-term } \\
\text { outcomes }\end{array}$ & 105 & 35 & All & Original research \\
\hline 4 & Ono $\mathrm{H}$ & $\begin{array}{l}\text { Dig Endosc } \\
\text { 2016;28:3-15 }\end{array}$ & $\begin{array}{l}\text { Guidelines for endoscopic submucosal } \\
\text { dissection and endoscopic mucosal } \\
\text { resection for early gastric cancer }\end{array}$ & 85 & 30 & Stomach & $\begin{array}{l}\text { Guideline/consensus } \\
\text { report }\end{array}$ \\
\hline 4 & Fujiya M & $\begin{array}{l}\text { Gastrointest Endosc } \\
\text { 2015;81:583-595 }\end{array}$ & $\begin{array}{l}\text { Efficacy and adverse events of EMR and } \\
\text { endoscopic submucosal dissection for } \\
\text { the treatment of colon neoplasms: a } \\
\text { meta-analysis of studies comparing } \\
\text { EMR and endoscopic submucosal } \\
\text { dissection }\end{array}$ & 85 & 22 & Colon & $\begin{array}{l}\text { Original research } \\
\text { (systematic } \\
\text { review/meta-analysis) }\end{array}$ \\
\hline 6 & Lee EJ & $\begin{array}{l}\text { Surg Endosc } \\
\text { 2013;27:31-39 }\end{array}$ & $\begin{array}{l}\text { Endoscopic submucosal dissection for } \\
\text { colorectal tumors--1,000 colorectal } \\
\text { ESD cases: one specialized institute's } \\
\text { experiences }\end{array}$ & 83 & 29 & Colon & Original research \\
\hline 7 & $\begin{array}{l}\text { Nishiyama } \\
\mathrm{N}\end{array}$ & $\begin{array}{l}\text { World J Gastroenterol } \\
\text { 2013;19:2752-2760 }\end{array}$ & $\begin{array}{l}\text { Efficacy and safety of over-the-scope } \\
\text { clip: including complications after } \\
\text { endoscopic submucosal dissection }\end{array}$ & 80 & 35 & All & Original research \\
\hline 7 & Oda I & $\begin{array}{l}\text { Dig Endosc 2013;25 } \\
\text { Suppl 1:71-78 }\end{array}$ & $\begin{array}{l}\text { Complications of gastric endoscopic } \\
\text { submucosal dissection }\end{array}$ & 80 & 35 & Stomach & Review \\
\hline 9 & Probst A & $\begin{array}{l}\text { Endoscopy } \\
\text { 2015;47:113-121 }\end{array}$ & $\begin{array}{l}\text { Early esophageal cancer in Europe: } \\
\text { endoscopic treatment by endoscopic } \\
\text { submucosal dissection }\end{array}$ & 70 & 33 & Esophagus & Original research \\
\hline 10 & Abe $S$ & $\begin{array}{l}\text { Endoscopy } \\
\text { 2013;45:703-707 }\end{array}$ & $\begin{array}{l}\text { Short- and long-term outcomes of } \\
\text { endoscopic submucosal dissection for } \\
\text { undifferentiated early gastric cancer }\end{array}$ & 69 & 33 & Stomach & Original research \\
\hline
\end{tabular}

The top 10 most cited articles of WoSCC bibliometrics in ESD research (2013 2017).

WoSCC, Web of Science Core Collection; ESD, endoscopic submucosal dissection; PMC, PubMed Central; EMR, endoscopic mucosal resection. 


\section{Data extraction and bibliometric analyses}

Each of the top 50 most-cited or -mentioned articles was examined for 1) citation counts from WoSCC, GS, and from PMC articles; 2) AAS; 3) title; 4) journal name with its impact factor and Eigenfactor ${ }^{\mathrm{TM}}$ score; ${ }^{11}$ 5) published year; 6) region (stomach vs. colon vs. esophagus vs. duodenum vs. all regions) of ESD; and 7) article type (original research vs. guideline/consensus report vs. review vs. case report).

A network-analysis was conducted to determine the most influential words in titles, abstracts, and of both titles and abstracts among the top 500 most-cited articles in WoSCC. Visualization was impossible when analysing the top 50 most-cited articles due to paucity of data; therefore, the analysis scheme was increased to the top 500 most-cited articles. ${ }^{12}$ The units of analysis were words in a title or abstract, and a full counting method was adopted-all occurrences of a term in a title or abstract were counted.

\section{Statistical analyses}

This study's primary outcome was a narrative synthesis of data. However, a quantitative synthesis was conducted to find correlations between citation counts from WoSCC or GS and those from PMC articles. The correlation coefficient was analysed using Pearson's correlation test; the partial correlation coefficient was analysed to control for confounding variables. To find the differences in citation counts according to the publication year, a Kruskal-Wallis test was performed. To find the differences in publication numbers of different regions of ESD according to the publication year, a Cochran-Armitage test for trend was executed. Harzing's Publish or Perish software version 6 was used for the citation analysis, ${ }^{10}$ and VOSviewer version 1.6.9 was used for the network analysis. ${ }^{12}$ A $P$-value $<0.05$ (two-tailed) was defined as the statistical significance threshold for all tests. All analyses were performed using SPSS version 22.0 (SPSS Inc., Chicago, IL, USA), except for the Cochran-Armitage test, which was completed using EpiTools calculators (http://epitools.ausvet.com.au/content.php?page=trend; Ausvet Pty Ltd, Bruce, Australia).

Table 2. Journals with Two or More of the Top 50 Most-cited Articles of WoSCC Bibliometrics in ESD Research

\begin{tabular}{|c|c|c|c|c|c|}
\hline Rank & Journal & $\begin{array}{l}\text { Number of published articles } \\
\text { in each journal among the } \\
\text { top-50 cited articles }\end{array}$ & $\begin{array}{c}\text { Journal impact } \\
\text { factor based on JCR } \\
2017\end{array}$ & Eigenfactor $^{\mathrm{TM}}$ score & Category by JCR \\
\hline 1 & Endoscopy & 10 & 6.629 & 0.018 & $\begin{array}{l}\text { Gastroenterology \& } \\
\text { hepatology/surgery }\end{array}$ \\
\hline 2 & Digestive Endoscopy & 9 & 3.375 & 0.005 & $\begin{array}{l}\text { Gastroenterology \& } \\
\text { hepatology/surgery }\end{array}$ \\
\hline 2 & Gastrointestinal Endoscopy & 9 & 7.204 & 0.034 & $\begin{array}{l}\text { Gastroenterology \& } \\
\text { hepatology }\end{array}$ \\
\hline 4 & $\begin{array}{l}\text { Surgical Endoscopy and } \\
\text { Other Interventional } \\
\text { Techniques }\end{array}$ & 6 & 3.117 & 0.042 & Surgery \\
\hline 5 & Gastric Cancer & 4 & 5.045 & 0.007 & $\begin{array}{l}\text { Gastroenterology \& } \\
\text { hepatology/oncology }\end{array}$ \\
\hline 6 & $\begin{array}{l}\text { World Journal of } \\
\text { Gastroenterology }\end{array}$ & 3 & 3.300 & 0.058 & $\begin{array}{l}\text { Gastroenterology \& } \\
\text { hepatology }\end{array}$ \\
\hline
\end{tabular}

Impact factor measures the number of citations to the journal in a given year by the number of articles published in that journal in the previous 2 years. Eigenfactor ${ }^{\mathrm{TM}}$ score is calculated based on the number citations to the journal in a given year by the number of articles published in that journal in the past 5 years. Unlike the 5-year journal impact factor, the Eigenfactor ${ }^{\mathrm{TM}}$ score excludes self-citation and assigns weight to each earned citation according to the citedness of the citing journal. ${ }^{11}$

WoSCC, Web of Science Core Collection; ESD, endoscopic submucosal dissection; JCR, journal citation reports. 


\section{RESULTS}

\section{Bibliometrics of WoSCC}

Table 1 lists the top 10 most-cited articles from WoSCC and Supplementary File 1 lists the top 50 most-cited articles from WoSCC including detailed information. The citation counts for the top 50 articles ranged from 37 to 199; the publication years ranged from 2013 to 2017. The top 50 articles were published in 15 different journals; Endoscopy published the largest share of articles (20\%), followed by Digestive Endoscopy/Gastrointestinal Endoscopy (18\%) (Table 2).

In the WoSCC bibliometrics of the top 50 most-cited articles, citations from PMC articles showed a significant correlation with those from WoSCC ( $\mathrm{r}=0.93, P<0.001)$. The result was consistent after controlling for publication year, region of ESD, and type of article (partial correlation coefficient=0.94, $P<0.001$ ). A Kruskal-Wallis test showed no significant difference $(P=0.12)$ in citation counts ac-

Table 3. The Top 10 Most-cited Articles of Google Scholar Bibliometrics in ESD Research (1999 2015)

\begin{tabular}{|c|c|c|c|c|c|c|c|}
\hline Rank & First author & Journal & Title & $\begin{array}{l}\text { Citation } \\
\text { counts } \\
\text { (Google } \\
\text { Scholar) }\end{array}$ & $\begin{array}{l}\text { Citation } \\
\text { counts } \\
\text { (PMC) }\end{array}$ & $\begin{array}{l}\text { Stomach vs. } \\
\text { colon vs. } \\
\text { esophagus } \\
\text { vs. } \\
\text { duodenum }\end{array}$ & Type of article \\
\hline 1 & Inoue $\mathrm{H}$ & $\begin{array}{l}\text { Endoscopy } \\
\text { 2010;42:265-271 }\end{array}$ & $\begin{array}{l}\text { Peroral endoscopic myotomy } \\
\text { (POEM) for esophageal achalasia }\end{array}$ & 1,195 & 171 & Esophagus & Original research \\
\hline 2 & Gotoda T & $\begin{array}{c}\text { Gastric Cancer } \\
2007 ; 10: 1-11\end{array}$ & $\begin{array}{l}\text { Endoscopic resection of early } \\
\text { gastric cancer }\end{array}$ & 667 & 137 & Stomach & Review \\
\hline 3 & Gotoda T & $\begin{array}{l}\text { J Gastroenterol } \\
\text { 2006;41:929-942 }\end{array}$ & $\begin{array}{l}\text { Endoscopic submucosal dissection } \\
\text { of early gastric cancer }\end{array}$ & 663 & 129 & Stomach & Review \\
\hline 3 & Oka S & $\begin{array}{l}\text { Gastrointest Endosc } \\
\text { 2006;64:877-883 }\end{array}$ & $\begin{array}{l}\text { Advantage of endoscopic } \\
\text { submucosal dissection compared } \\
\text { with EMR for early gastric cancer }\end{array}$ & 663 & 138 & Stomach & Original research \\
\hline 5 & Oyama T & $\begin{array}{l}\text { Clin Gastroenterol } \\
\text { Hepatol 2005;3(7 } \\
\text { Suppl 1):S67-S70 }\end{array}$ & $\begin{array}{l}\text { Endoscopic submucosal dissection } \\
\text { of early esophageal cancer }\end{array}$ & 581 & 129 & Esophagus & Original research \\
\hline 6 & Isomoto $\mathrm{H}$ & Gut 2009;58:331-336 & $\begin{array}{l}\text { Endoscopic submucosal dissection } \\
\text { for early gastric cancer: a } \\
\text { large-scale feasibility study }\end{array}$ & 541 & 136 & Stomach & Original research \\
\hline 7 & Oda I & $\begin{array}{l}\text { Dig Endosc } \\
2005 ; 17: 54-58\end{array}$ & $\begin{array}{l}\text { Endoscopic submucosal dissection } \\
\text { for early gastric cancer: technical } \\
\text { feasibility, operation time and } \\
\text { complications from a large } \\
\text { consecutive series }\end{array}$ & 530 & $\begin{array}{c}\text { Not } \\
\text { available }\end{array}$ & Stomach & Original research \\
\hline 8 & Chung IK & $\begin{array}{l}\text { Gastrointest Endosc } \\
\text { 2009;69:1228-1235 }\end{array}$ & $\begin{array}{l}\text { Therapeutic outcomes in } 1000 \text { cases } \\
\text { of endoscopic submucosal } \\
\text { dissection for early gastric } \\
\text { neoplasms: Korean ESD Study } \\
\text { Group multicenter study }\end{array}$ & 505 & 125 & Stomach & Original research \\
\hline 8 & Saito Y & $\begin{array}{l}\text { Gastrointest Endosc } \\
2010 ; 72: 1217-1225\end{array}$ & $\begin{array}{l}\text { A prospective, multicenter study of } \\
1111 \text { colorectal endoscopic } \\
\text { submucosal dissections (with } \\
\text { video) }\end{array}$ & 505 & 109 & Stomach & Original research \\
\hline 10 & Tanaka S & $\begin{array}{l}\text { Gastrointest Endosc } \\
\text { 2007;66:100-107 }\end{array}$ & $\begin{array}{l}\text { Endoscopic submucosal dissection } \\
\text { for colorectal neoplasia: } \\
\text { possibility of standardization }\end{array}$ & 494 & 82 & Colon & Original research \\
\hline
\end{tabular}

ESD, endoscopic submucosal dissection; PMC, PubMed Central. 
cording to the publication year.

Of the top 50 most-cited articles, original research comprised $78 \%$, review $14 \%$, guidelines or consensus reports $6 \%$, and case series $2 \%$. The proportion of systematic reviews/meta-analyses was 8\% (Supplementary File 1).

For the region of ESD in each study, stomach comprised $32 \%$, colon $30 \%$, esophagus $20 \%$, all regions $12 \%$, and duodenum 6\%. A Cochran-Armitage test for trends showed no significant difference $(P=0.48)$ in publication numbers on different regions of ESD from WoSCC according to the publication year.

\section{Bibliometrics of $\mathrm{GS}$}

Table 3 lists the top 10 most-cited articles from GS, and Supplementary File 2 lists the top 50 most-cited articles from GS. The citation number for the top 50 most-cited articles found through GS ranged from 221 to 1,195 and the publication years ranged from 1999 to 2015. The top 50 most-cited articles were published in 12 different journals. Gastrointestinal Endoscopy published the largest share of articles (34\%), followed by Endoscopy (22\%) (Supplementary Table 1).

The GS bibliometrics of the top 50 most-cited articles indicated that the citations of PMC articles were significantly correlated with those from GS ( $\mathrm{r}=0.80, P<0.001)$. The result was consistent after controlling for publication year, region of ESD, and type of article (partial correlation coefficient $=0.81$, $P<0.001$ ). A Kruskal-Wallis test showed no significant difference $(P=0.38)$ in citation counts according to the publication year.

Original research comprised $90 \%$, review $8 \%$, guidelines or consensus reports $2 \%$, and systematic reviews/meta-analyses $4 \%$ of the top-50 cited articles (Supplementary File 2).

For the region of ESD in each study, stomach comprised $50 \%$, esophagus $24 \%$, colon $16 \%$, and all regions $10 \%$ of the top 50 most-cited articles of GS bibliometrics. A Cochran-Armitage test for trends showed no significant difference $(P=0.05)$ in publication numbers on different regions of ESD from GS according to the publication year.

\section{Bibliometrics of GS published after 2015}

Among the top 1,000 most-cited articles on GS bibliometrics, there were 50 papers published between 2015 and 2017. Supplementary Table 2 lists the top 10 most-cited articles on GS published after 2015, and Supplementary File 3 lists the top 50 most-cited articles on GS published after 2015 among the top 1,000 most-cited articles. The citation counts ranged from 24 to 323; the publication years ranged from 2015 to 2017. The top 50 most-cited articles were published in 19 different journals; Endoscopy published the largest share of articles (20\%), followed by Gastrointestinal Endoscopy (18\%) (Supplementary Table 3).

In the GS bibliometrics of the top 50 most-cited articles published after 2015, citations of PMC articles showed a significant correlation with those from GS ( $\mathrm{r}=0.96, P<0.001)$. The result was consistent after controlling for publication year, region of ESD, and type of article (partial correlation coefficient $=0.91, P<0.001$ ). A Kruskal-Wallis test showed no significant difference $(P=0.45)$ in citation counts according to the publication year.

Of the top 50 most-cited articles published after 2015, original research comprised $88 \%$, review $6 \%$, guidelines or consensus reports $6 \%$, and systematic reviews/meta-analyses 10\% (Supplementary File 3).

For the region of ESD in each study, stomach comprised $38 \%$, esophagus $32 \%$, colon $22 \%$, all regions $6 \%$, and duodenum 2\%. A Cochran-Armitage test for trends showed no significant difference $(P=0.46)$ in publication numbers on different regions of ESD according to the publication year.

\section{Bibliometrics of AAS}

Supplementary Table 4 lists the top 10 AAS articles, and Supplementary File 4 lists the top 50 AAS articles. The AAS for the top 50 most-mentioned articles in online media ranged from 6 to 21. The publication years ranged from 2006 to 2019. The citation counts of PMC articles for the top 50 most-cited AAS articles ranged from 0 to 55. The top 50 most-cited AAS articles were published in 15 different journals. Gastrointestinal Endoscopy published 


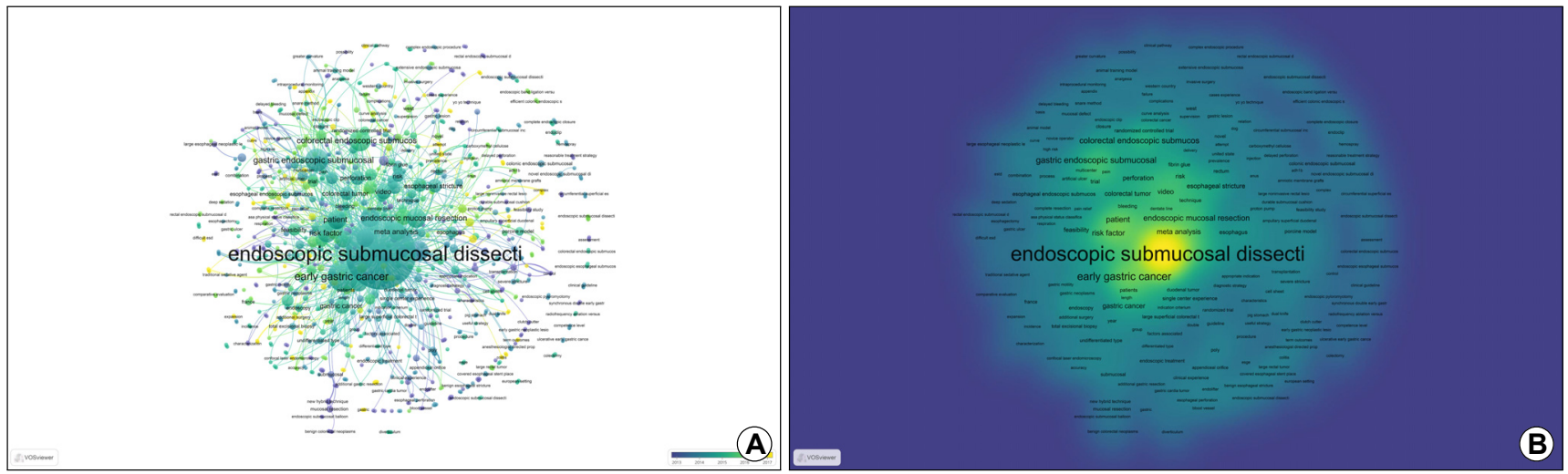

Fig. 1. Network plot of influential title words in endoscopic submucosal dissection research among the top 500 most cited articles of Web of Science Core Collection. (A) Overlay visualization. Each node is colored based on its score and the modularity clustering technique. ${ }^{14}$ (B) Density visualization of (A). The larger the number of items in the neighborhood of a node and the higher the weights of the neighboring items, the closer in color the point is to yellow. The smaller the number of items in the neighborhood of a node and the lower the weights of the neighboring items, the closer in color the point is to blue. ${ }^{14}$

the largest share of articles (42.6\%), followed by VideoGIE (29.5\%) (Supplementary Table 5).

In the top 50 most-cited AAS articles, citations of PMC articles showed no correlation with AAS ( $\mathrm{r}=-0.05, P=0.68)$. The result was consistent after controlling for publication year, region of ESD, and type of article (partial correlation coefficient=-0.05, $P=0.74)$. A Kruskal-Wallis test showed no significant difference $(P=0.36)$ in citation counts according to the publication year.

Of the top 50 AAS articles, original research comprised $60.7 \%$, case reports $31.1 \%$, review $6.6 \%$, guidelines or consensus reports $1.6 \%$, and systematic reviews/meta-analyses 6.6\% (Supplementary File 4).

For the region of ESD in each study, colon comprised $42.6 \%$, stomach $26.2 \%$, esophagus $23 \%$, duodenum $6.6 \%$, and all regions $1.6 \%$. A Cochran-Armitage test for trends showed no significant difference $(P=0.38)$ in publication numbers on different regions of ESD from AAS bibliometrics according to the publication year.

\section{Network-analysis for the most influential words in titles, abstracts, and of both titles and abstracts among the top 500 most-cited articles in WoSCC}

Among the 1,040 words in the titles of the most-cited articles, Supplementary Table 6 lists the words with high relevance-score. Words or terms with a high relevance-score included 'colorectal ESD/EMR,' 'gastric ESD,' 'submucosal tunnel dissection,' 'guideline,' 'novel submucosal gel,' and 'esophageal squamous cell neoplasia. ${ }^{13}$ Fig. 1A demonstrates the overlay visualization with no normalization layout. Fig. $1 \mathrm{~B}$ demonstrates the density visualization of Fig. $1 \mathrm{~A}^{14}$ The following were influential title-words: 'early gastric cancer (EGC),' 'meta-analysis,' 'risk factor,' 'esophageal stricture,' 'perforation,' 'bleeding,' 'colorectal tumor,' 'feasibility,' 'technique,' 'esophagus,' 'fibrin glue,' 'artificial ulcer,' 'porcine model,' etc.

Among the 7,293 words in abstracts, Supplementary Table 7 lists the words with high relevance-score. Words or terms with a high relevance-score included 'adhesive material,' 'cell sheet technology,' 'cultured autologous oral mucosal epithelial cell sheet,' and 'esophageal ulcer.' Fig. 2A demonstrates the overlay visualization with association strength layout and Fig. 2B demonstrates the density visualization of Fig. 2A. The following were influential abstract-words: 'en bloc resection,' 'recurrence,' 'second look endoscopy,' 'EGC,' 'endoscopic ultrasound,' 'neoplasia,' 'lymphovascular invasion,' 'additional surgical resection,' 'curative ESD,' 'ulcer healing,' 'rebamipide,' 'metastasis,' 'extragastric recurrence,' 'active bleeding,' 'proton pump inhibitor,' 'device,' ' $\mathrm{CO}_{2}$ insufflation,' 'sedation,' 'speed,' etc.

Among the 7,691 words in the titles and abstracts, Supplementary Table 8 lists the words with high rele- 

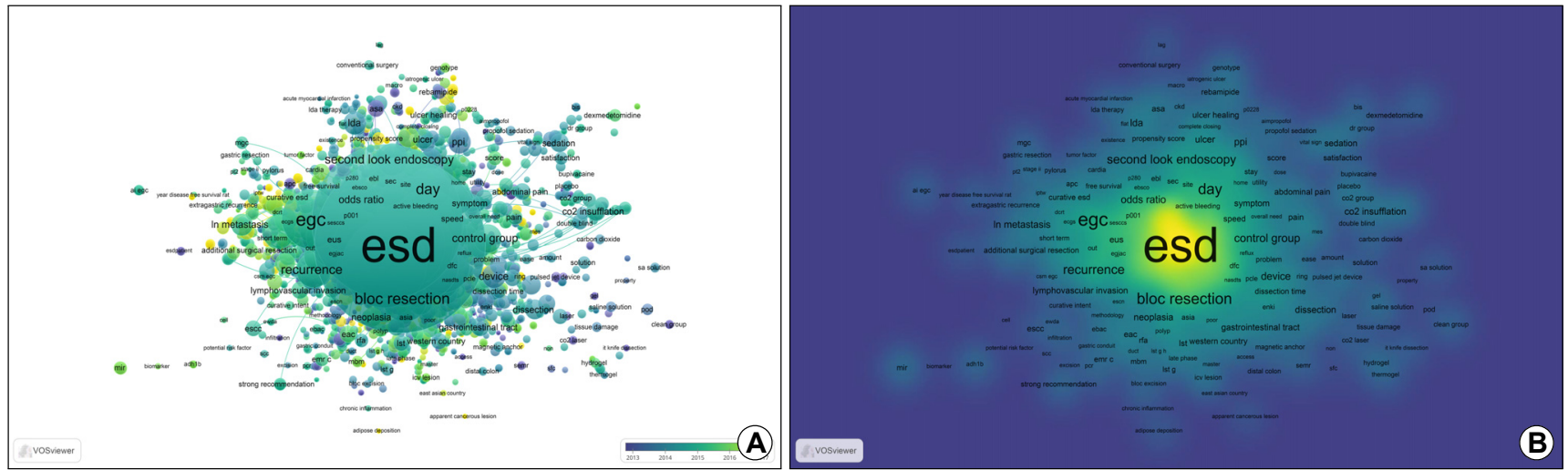

Fig. 2. Network plot of influential abstract words in endoscopic submucosal dissection (ESD) research among the top 500 most cited articles of Web of Science Core Collection. (A) Overlay visualization. (B) Density visualization of (A).
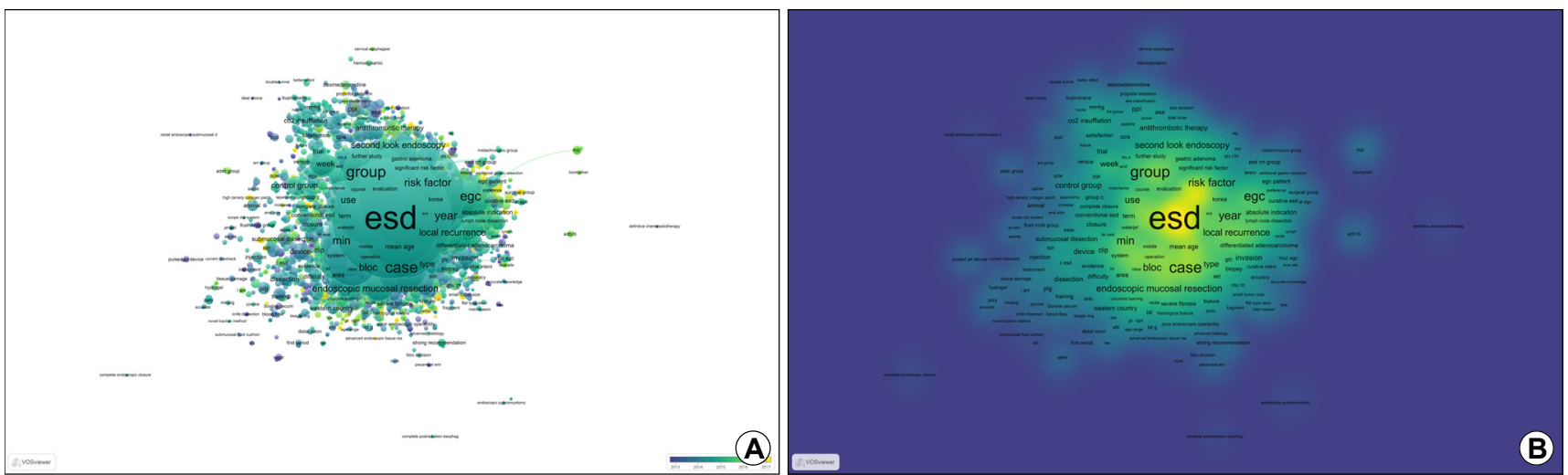

Fig. 3. Network plot of influential words in abstracts and titles of endoscopic submucosal dissection (ESD) research among the top 500 most cited articles of Web of Science Core Collection. (A) Overlay visualization. (B) Density visualization of (A).

vance-scores. Fig. 3A demonstrates the overlay visualization with linlog layout and Fig. 3B demonstrates the density visualization of Fig. 3A. The following were influential words and terms in the titles and abstracts: 'perforation,' 'efficacy,' 'adverse event,' 'EGC,' 'curative resection,' 'bleeding,' 'esophageal stricture,' 'colorectal ESD,' 'colorectal tumor,' 'EMR,' 'tumor size,' 'gastric ESD,' 'bleeding,' 'risk factor,' 'second look endoscopy,' 'delayed bleeding,' 'post ESD bleeding,' 'elderly patients,' 'surgery,' 'technical difficulty,' 'adenoma,' etc.

\section{DISCUSSION}

The citations of PMC articles among the top 50 WoSCC or GS articles showed a significant correlation with those from each bibliometrics; however, AAS was not correlated. This was consistent with previous studies exploring the association between altmetric indicators and citation counts. $^{15,16}$ A recent bibliometric analysis of neurointervention articles also suggested that AAS operates independently of citations and can be used as an alternative index for measuring an article's impact. ${ }^{17}$ Considering that attention itself does not reflect the quality of research, AAS might not represent a qualified impact in specialized academic fields; however, information will no longer be inaccessible, and AAS, as a disseminative impact, might be a complementary indicator in the evaluation of the impact of a specific article. ${ }^{4}$

In terms of the topic of all four bibliometrics, guidelines or evidence-based technical reviews of each aca- 
demic society ${ }^{18-21}$ were common in the WoSCC or GS top 50 most-cited articles published after 2015, including recent citations. Studies with emerging issues, such as management of ESD-induced gastric perforation with an over-the-scope clip, ${ }^{22}$ ESD of early esophageal cancers ${ }^{23}$ or superficial Barrett's neoplasia, ${ }^{24,25}$ ESD of EGC with undifferentiated-type histology, ${ }^{26}$ therapeutic outcomes of $\mathrm{POEM}^{27}$ or natural orifice transluminal endoscopic surgery techniques, such as laparoscopic endoscopic cooperative surgery $^{28}$ were noted in the WoSCC or GS top 50 most-cited articles published after 2015, including recent citations. Large-scale cohort studies with over 1,000 cases that evaluated the efficacy and safety of ESD were also common in the WoSCC or GS top 50 bibliometrics. ${ }^{29-34}$

Upon increasing the analysis scheme to GS top 50 bibliometrics, many milestone papers and expert review articles that provided evidence for current practice standardization were included. A study on the introduction of POEM ${ }^{35}$ and review publications that greatly affected the standardization of gastric ESD techniques, indications, and procedures were also included. ${ }^{36,37}$ In addition to gastric ESD, earlier studies that influenced the widespread use of ESD in the esophagus or colorectal area were included. ${ }^{38,39}$

The composition of the top 10 most-cited AAS articles were slightly different from other bibliometrics. Additional validation of topics that may already be considered as having sufficient evidence were noted, such as a comparison of long-term outcomes of gastric ESD with surgery for EGCs that fulfilled the expanded indication, ${ }^{40}$ or therapeutic outcomes of ESD of differentiated $\mathrm{EGCS}^{41}$ or colorectal tumors ${ }^{42}$ in Western countries. Studies that compared EMR with ESD for the treatment of superficial colorectal neoplasia ${ }^{43-45}$ received attention from various audiences. Studies about the development and validation of novel ESD techniques, such as endoscopic mucosa-sparing lateral dissection for the treatment of gastric subepithelial tumours or ESD for subepithelial tumours of the colon and rectum also received attention. ${ }^{46,47}$ Studies on emerging issues, such as the Western ESD trial on superficial Barrett's neoplasia ${ }^{48}$ or the transplantation of autologous esophageal mucosa to prevent stricture after circumferential ESD of esophagus ${ }^{49}$ were included. Upon increasing the analysis scheme to the top 50 most-cited AAS articles, most of the articles were video cases published in VideoGIE.

In terms of the subject categories of published journals, 'Gastroenterology and Hepatology' (especially, endoscopy-related journals such as Gastrointestinal Endoscopy, Endoscopy, Digestive Endoscopy, Surgical Endoscopy and Other Interventional Techniques) was prevalent in all of the bibliometrics. However, other categories such as 'Surgery,' 'Oncology,' or 'Medicine, General, and Internal' were also prevalent, indicating that ESD research is not confined to one specialized academic field and journals with wider readerships are also eligible to publish research on ESD.

Original research was common in all of the top 50 bibliometrics (60.7 90\%); however, video cases were also prevalent (31.1\%) in top 50 AAS bibliometrics. Guidelines/consensus reports (1.6 6\%) and systematic reviews/ meta-analyses (4 10\%) were prevalent and in the upper ranks of all bibliometrics, likely due to the consolidated and quantitative review of the large, complex, and sometimes conflicting field of articles in this era of overflowing publications.

For the region of ESD in each set of bibliometrics, stomach comprised 50\% in GS bibliometrics (esophagus: 24\%, colon: 16\%); however, the proportion of colon and esophagus was increased in the bibliometrics of WoSCC (stomach: 32\%, colon: 30\%, esophagus: 20\%) and GS published after 2015 (stomach: 38\%, esophagus: 32\%, colon: $22 \%$ ), while the proportion of colon was most prevalent in the AAS bibliometrics (colon: $42.6 \%$, stomach: $26.2 \%$, esophagus: $23 \%$ ).

A network-analysis of influential words in the titles or abstracts among the top 500 most-cited articles on WoSCC showed the recent interest of researchers relevant to ESD research. Words and terms with high relevance-scores were 'submucosal tunnel dissection,' 'guideline,' 'novel submucosal gel,' 'adhesive material,' 'cell sheet,' 'esophageal ulcer,' 'hemospray,' and 'complete endoscopic closure,' and the following words and terms were influential: 'meta-analysis,' 'esophageal stricture,' 'perforation,' 'bleeding,' 'fibrin glue,' 'artificial ulcer,' 'porcine model,' 'esophageal squamous cell neoplasia,' excluding 'ESD.'

To the best of our knowledge, this is the first study using bibliometric analysis relevant to ESD research. We adopted 
various bibliometric sources with in-depth analyses of citation counts, journals, publication years, and words in titles and abstracts. Despite its strengths, this study has limitations. First, only the 'number of citations' was adopted as a bibliometric index, excluding various other indices (such as article influence score, cited half-life or immediacy index, etc.). Previous studies exploring the impact of each bibliometric index suggested the significance and importance of specific bibliometric indices representing influence in each academic field. ${ }^{50,51}$ However, there has been no study stated above in the field of gastroenterology and we could adopt only 'number of citations' as a bibliometric index. Another limitation was that the number of top 50 most-cited articles might be insufficient in determining the most influential articles on ESD research. Visualization of network-analysis to determine the most influential title-words was impossible among the top 50 most-cited articles and this scheme should be increased to the top 500 most-cited articles.

In conclusion, this study can help researchers identify the most influential articles on ESD and provide insight into the most noteworthy scientific trends and to visualize future research needs of the topic.

\section{ACKNOWLEDGEMENT}

This research was supported by the Bio \& Medical Technology Development Program of the National Research Foundation (NRF) and funded by the Korean government, Ministry of Science and ICT (MSIT) (grant number NRF2017M3A9E8033253).

\section{CONFLICT OF INTEREST}

No potential conflict of interest relevant to this article was reported.

\section{ORCID}

Chang Seok Bang (10 https://orcid.org/0000-0003-4908-5431

Jae Jun Lee (1) https://orcid.org/0000-0002-5418-500X

Gwang Ho Baik (1) https://orcid.org/0000-0003-1419-7484

\section{REFERENCES}

1. Li H, Zhao X, Zheng P, et al. Classic citations in main primary health care journals: a PRISMA-compliant systematic literature review and bibliometric analysis. Medicine (Baltimore) 2015; 94:e2219.

2. Delgado-López PD, Corrales-García EM. Influence of internet and social media in the promotion of alternative oncology, cancer quackery, and the predatory publishing phenomenon. Cureus 2018;10:e2617.

3. Bang CS, Baik GH. Social network analysis: type of information and characteristics of its delivery regarding Helicobacter pylori in Korea. Korean J Helicobacter Up Gastrointest Res 2016;16: 198-203.

4. Trueger NS, Thoma B, Hsu CH, Sullivan D, Peters L, Lin M. The altmetric score: a new measure for article-level dissemination and impact. Ann Emerg Med 2015;66:549-553.

5. Citrome L. Moving forward with article level metrics: introducing altmetrics. Int J Clin Pract 2015;69:811.

6. Clarivate Analytics. Web of Science Core Collection Descriptive Document. 2018 [Internet]. NY: Web of Science [cited 2019 Feb 1]. Available from: https://clarivate.libguides.com/ld. php?content_id=45175981.

7. Google Scholar. Search Tips [Internet]. Mountain View: Google Scholar [cited 2019 Feb 1]. Available from: https://scholar.google.com/intl/us/scholar/help.html\#coverage.

8. Gusenbauer M. Google Scholar to overshadow them all? Comparing the sizes of 12 academic search engines and bibliographic databases. Scientometrics 2019;118:177-214.

9. Delgado-López-Cózar E, Cabezas-Clavijo Á. Ranking journals: could google scholar metrics be an alternative to journal citation reports and Scimago journal rank? Learned Publishing 2013;26:101-114.

10. Anne-Wil H. Publish or Perish, 2020 [Internet]. Harzing.com [cited 2019 Feb 1]. Available from: https://harzing.com/resources/ publish-or-perish.

11. Eigenfactor ${ }^{\circledR}$. Eigenfactor: Revealing the Structure of Science [Internet]. Eigenfactor ${ }^{\circledR}$ [cited 2019 Feb 1]. Available from: http://www.eigenfactor.org/.

12. Centre for Science and Technology Studies, Leiden University. VOSviewer [Internet]. South Holland: Centre for Science and Technology Studies, Leiden University [cited 2019 Feb 1]. Available from: https://www.vosviewer.com/.

13. Van Eck NJ, Waltman L. Visualizing bibliometric networks. In: Ding Y, Rousseau R, Wolfram D, eds. Measuring scholarly impact: methods and practice. Heidelberg: Springer, 2014: 285-320.

14. Van Eck NJ, Waltman L. VOSviewer Manual, 2016 [Internet]. CWTS [cited 2019 Feb 1]. Available from: http://www.vosviewer. com/documentation/Manual_VOSviewer_1.6.5.pdf.

15. Costas R, Zahedi Z, Wouters P. Do "altmetrics" correlate with citations? Extensive comparison of altmetric indicators with citations from a multidisciplinary perspective. J Assoc Inf Sci Tech 
2015;66:2003-2019.

16. Rosenkrantz AB, Ayoola A, Singh K, Duszak R Jr. Alternative metrics ("Altmetrics") for assessing article impact in popular general radiology journals. Acad Radiol 2017;24:891-897.

17. Kim HJ, Yoon DY, Kim ES, et al. The most mentioned neurointervention articles in online media: a bibliometric analysis of the top 101 articles with the highest altmetric attention scores. J Neurointerv Surg 2019;11:528-532.

18. Pimentel-Nunes P, Dinis-Ribeiro M, Ponchon T, et al. Endoscopic submucosal dissection: European Society of Gastrointestinal Endoscopy (ESGE) guideline. Endoscopy 2015;47:829-854.

19. Tanaka S, Kashida H, Saito Y, et al. JGES guidelines for colorectal endoscopic submucosal dissection/endoscopic mucosal resection. Dig Endosc 2015;27:417-434.

20. Ono H, Yao K, Fujishiro M, et al. Guidelines for endoscopic submucosal dissection and endoscopic mucosal resection for early gastric cancer. Dig Endosc 2016;28:3-15.

21. ASGE Technology Committee, Maple JT, Abu Dayyeh BK, et al. Endoscopic submucosal dissection. Gastrointest Endosc 2015; 81:1311-1325.

22. Nishiyama N, Mori H, Kobara H, et al. Efficacy and safety of over-the-scope clip: including complications after endoscopic submucosal dissection. World J Gastroenterol 2013;19: 2752-2760.

23. Probst A, Aust D, Märkl B, Anthuber M, Messmann H. Early esophageal cancer in Europe: endoscopic treatment by endoscopic submucosal dissection. Endoscopy 2015;47:113-121.

24. Terheggen G, Horn EM, Vieth M, et al. A randomised trial of endoscopic submucosal dissection versus endoscopic mucosal resection for early Barrett's neoplasia. Gut 2017;66:783-793.

25. Chevaux JB, Piessevaux H, Jouret-Mourin A, Yeung R, Danse E, Deprez PH. Clinical outcome in patients treated with endoscopic submucosal dissection for superficial Barrett's neoplasia. Endoscopy 2015;47:103-112.

26. Abe S, Oda I, Suzuki H, et al. Short- and long-term outcomes of endoscopic submucosal dissection for undifferentiated early gastric cancer. Endoscopy 2013;45:703-707.

27. Familiari P, Gigante G, Marchese M, et al. Peroral endoscopic myotomy for esophageal achalasia: outcomes of the first 100 patients with short-term follow-up. Ann Surg 2016;263:82-87.

28. Hiki N, Nunobe S, Matsuda T, Hirasawa T, Yamamoto Y, Yamaguchi T. Laparoscopic endoscopic cooperative surgery. Dig Endosc 2015;27:197-204.

29. Toyonaga T, Man-i M, East JE, et al. 1,635 Endoscopic submucosal dissection cases in the esophagus, stomach, and colorectum: complication rates and long-term outcomes. Surg Endosc 2013;27:1000-1008.

30. Lee EJ, Lee JB, Lee SH, et al. Endoscopic submucosal dissection for colorectal tumors--1,000 colorectal ESD cases: one specialized institute's experiences. Surg Endosc 2013;27:31-39.

31. Oka S, Tanaka S, Kaneko I, et al. Advantage of endoscopic submucosal dissection compared with EMR for early gastric cancer. Gastrointest Endosc 2006;64:877-883.

32. Oda I, Gotoda T, Hamanaka H, et al. Endoscopic submucosal dissection for early gastric cancer: technical feasibility, operation time and complications from a large consecutive series. Dig Endosc 2005;17:54-58.

33. Chung IK, Lee JH, Lee SH, et al. Therapeutic outcomes in 1000 cases of endoscopic submucosal dissection for early gastric neoplasms: Korean ESD Study Group multicenter study. Gastrointest Endosc 2009;69:1228-1235.

34. Saito Y, Uraoka T, Yamaguchi Y, et al. A prospective, multicenter study of 1111 colorectal endoscopic submucosal dissections (with video). Gastrointest Endosc 2010;72:1217-1225.

35. Inoue $\mathrm{H}$, Minami $\mathrm{H}$, Kobayashi $\mathrm{Y}$, et al. Peroral endoscopic myotomy (POEM) for esophageal achalasia. Endoscopy 2010;42: 265-271.

36. Gotoda T. Endoscopic resection of early gastric cancer. Gastric cancer 2007;10:1-11.

37. Gotoda T, Yamamoto H, Soetikno RM. Endoscopic submucosal dissection of early gastric cancer. J Gastroenterol 2006;41: 929-942.

38. Oyama T, Tomori A, Hotta K, et al. Endoscopic submucosal dissection of early esophageal cancer. Clin Gastroenterol Hepatol 2005;3:S67-S70.

39. Tanaka S, Oka S, Kaneko I, et al. Endoscopic submucosal dissection for colorectal neoplasia: possibility of standardization. Gastrointest Endosc 2007;66:100-107.

40. Hahn KY, Park CH, Lee YK, et al. Comparative study between endoscopic submucosal dissection and surgery in patients with early gastric cancer. Surg Endosc 2018;32:73-86.

41. Emura F, Mejía J, Donneys A, et al. Therapeutic outcomes of endoscopic submucosal dissection of differentiated early gastric cancer in a Western endoscopy setting (with video). Gastrointest Endosc 2015;82:804-811.

42. Milano RV, Viale E, Bartel MJ, Notaristefano C, Testoni PA. Resection outcomes and recurrence rates of endoscopic submucosal dissection (ESD) and hybrid ESD for colorectal tumors in a single Italian center. Surg Endosc 2018;32:2328-2339.

43. Fuccio L, Repici A, Hassan C, et al. Why attempt en bloc resection of non-pedunculated colorectal adenomas? A systematic review of the prevalence of superficial submucosal invasive cancer after endoscopic submucosal dissection. Gut 2018;67: 1464-1474.

44. Backes Y, Moons LM, van Bergeijk JD, et al. Endoscopic mucosal resection (EMR) versus endoscopic submucosal dissection (ESD) for resection of large distal non-pedunculated colorectal adenomas (MATILDA-trial): rationale and design of a multicenter randomized clinical trial. BMC Gastroenterol 2016;16: 56.

45. Saunders BP, Tsiamoulos ZP. Endoscopic mucosal resection and endoscopic submucosal dissection of large colonic polyps. Nat Rev Gastroenterol Hepatol 2016;13:486-496.

46. Li Y, Zhang Q, Zhu C, et al. Endoscopic mucosa-sparing lateral dissection for treatment of gastric submucosal tumors: a prospective cohort study. Endoscopy 2018;50:886-890.

47. Qi ZP, Shi Q, Liu JZ, et al. Efficacy and safety of endoscopic submucosal dissection for submucosal tumors of the colon and 
rectum. Gastrointest Endosc 2018;87:540-548.e1.

48. Subramaniam S, Chedgy F, Longcroft-Wheaton G, et al. Complex early Barrett's neoplasia at 3 western centers: European Barrett's endoscopic submucosal dissection trial (E-BEST). Gastrointest Endosc 2017;86:608-618.

49. Liao Z, Liao G, Yang X, et al. Transplantation of autologous esophageal mucosa to prevent stricture after circumferential endoscopic submucosal dissection of early esophageal cancer (with video). Gastrointest Endosc 2018;88:543-546.

50. Diaz-Ruiz A, Orbe-Arteaga U, Rios C, Roldan-Valadez E.
Alternative bibliometrics from the web of knowledge surpasses the impact factor in a 2-year ahead annual citation calculation: linear mixed-design models' analysis of neuroscience journals. Neurol India 2018;66:96-104.

51. Roldan-Valadez E, Orbe-Arteaga U, Rios C. Eigenfactor score and alternative bibliometrics surpass the impact factor in a 2-years ahead annual-citation calculation: a linear mixed design model analysis of Radiology, Nuclear Medicine and Medical Imaging journals. Radiol Med 2018;123:524-534. 
Supplementary Table 1. Journals with Two or More of the Top 50 Most-cited Articles of Google Scholar Bibliometrics in Endoscopic Submucosal Dissection Research

\begin{tabular}{|c|c|c|c|c|c|}
\hline Rank & Journal & $\begin{array}{l}\text { Number of published articles } \\
\text { in each journal among the } \\
\text { top-50 cited articles }\end{array}$ & $\begin{array}{l}\text { Journal impact fac- } \\
\text { tor based on JCR } \\
2017\end{array}$ & Eigenfactor ${ }^{\mathrm{TM}}$ score & Category by JCR \\
\hline 1 & Gastrointestinal Endoscopy & 17 & 7.204 & 0.034 & $\begin{array}{l}\text { Gastroenterology \& } \\
\text { hepatology }\end{array}$ \\
\hline 2 & Endoscopy & 11 & 6.629 & 0.018 & $\begin{array}{l}\text { Gastroenterology \& } \\
\text { hepatology/surgery }\end{array}$ \\
\hline 3 & $\begin{array}{l}\text { Surgical Endoscopy and } \\
\text { Other Interventional } \\
\text { Techniques }\end{array}$ & 4 & 3.117 & 0.042 & Surgery \\
\hline 4 & $\begin{array}{l}\text { Clinical Gastroenterology } \\
\text { and Hepatology }\end{array}$ & 3 & 7.683 & 0.038 & $\begin{array}{l}\text { Gastroenterology \& } \\
\text { hepatology }\end{array}$ \\
\hline 4 & Gastric Cancer & 3 & 5.045 & 0.007 & $\begin{array}{l}\text { Gastroenterology \& } \\
\text { hepatology/oncology }\end{array}$ \\
\hline 4 & Gut & 3 & 17.016 & 0.065 & $\begin{array}{l}\text { Gastroenterology \& } \\
\text { hepatology }\end{array}$ \\
\hline 7 & Digestive Endoscopy & 2 & 3.375 & 0.005 & $\begin{array}{l}\text { Gastroenterology \& } \\
\text { hepatology/surgery }\end{array}$ \\
\hline 7 & Gastroenterology & 2 & 20.773 & 0.132 & $\begin{array}{l}\text { Gastroenterology \& } \\
\text { hepatology }\end{array}$ \\
\hline 7 & Journal of Gastroenterology & 2 & 5.561 & 0.013 & $\begin{array}{l}\text { Gastroenterology \& } \\
\text { hepatology }\end{array}$ \\
\hline
\end{tabular}

JCR, journal citation reports. 
Supplementary Table 2. The Top 50 Most-cited Articles of Google Scholar Bibliometrics in Endoscopic Submucosal Dissection Research Published after 2015 among the Top 1,000 Most-cited Articles (2015-2017)

\begin{tabular}{|c|c|c|c|c|c|c|c|}
\hline Rank & First author & Journal & Title & $\begin{array}{l}\text { Citation } \\
\text { counts } \\
(\mathrm{GS})\end{array}$ & $\begin{array}{l}\text { Citation } \\
\text { counts } \\
(\mathrm{PMC})\end{array}$ & $\begin{array}{l}\text { Stomach vs. } \\
\text { colon vs. } \\
\text { esophagus } \\
\text { vs. } \\
\text { duodenum }\end{array}$ & Type of article \\
\hline 1 & $\begin{array}{l}\text { Pimentel-Nu } \\
\text { nes P }\end{array}$ & $\begin{array}{l}\text { Endoscopy } \\
2015 ; 47: 829-84\end{array}$ & $\begin{array}{l}\text { Endoscopic submucosal } \\
\text { dissection: European Society of } \\
\text { Gastrointestinal Endoscopy } \\
\text { (ESGE) guideline }\end{array}$ & 323 & 78 & All & $\begin{array}{l}\text { Guideline/consensus } \\
\text { report }\end{array}$ \\
\hline 2 & Tanaka S & $\begin{array}{l}\text { Dig Endosc } \\
\text { 2015;27:417-434 }\end{array}$ & $\begin{array}{l}\text { JGES guidelines for colorectal } \\
\text { endoscopic submucosal } \\
\text { dissection/endoscopic mucosal } \\
\text { resection }\end{array}$ & 198 & 48 & Colon & $\begin{array}{l}\text { Guideline/consensus } \\
\text { report }\end{array}$ \\
\hline 3 & Ono $\mathrm{H}$ & $\begin{array}{l}\text { Dig Endosc } \\
\text { 2016;28:3-15 }\end{array}$ & $\begin{array}{l}\text { Guidelines for endoscopic } \\
\text { submucosal dissection and } \\
\text { endoscopic mucosal resection } \\
\text { for early gastric cancer }\end{array}$ & 159 & 30 & Stomach & $\begin{array}{l}\text { Guideline/consensus } \\
\text { report }\end{array}$ \\
\hline 4 & Fujiya M & $\begin{array}{l}\text { Gastrointest Endosc } \\
\text { 2015;81:583-595 }\end{array}$ & $\begin{array}{l}\text { Efficacy and adverse events of } \\
\text { EMR and endoscopic } \\
\text { submucosal dissection for the } \\
\text { treatment of colon neoplasms: a } \\
\text { meta-analysis of studies } \\
\text { comparing EMR and } \\
\text { endoscopic submucosal } \\
\text { dissection }\end{array}$ & 112 & 22 & Colon & $\begin{array}{l}\text { Original research } \\
\text { (systematic review/ } \\
\text { meta-analysis) }\end{array}$ \\
\hline 5 & Probst A & $\begin{array}{l}\text { Endoscopy } \\
\text { 2015;47:113-121 }\end{array}$ & $\begin{array}{l}\text { Early esophageal cancer in } \\
\text { Europe: endoscopic treatment } \\
\text { by endoscopic submucosal } \\
\text { dissection }\end{array}$ & 103 & 30 & Esophagus & Original research \\
\hline 6 & Familiari P & $\begin{array}{l}\text { Ann Surg } \\
\text { 2016;263:82-87 }\end{array}$ & $\begin{array}{l}\text { Peroral endoscopic myotomy for } \\
\text { esophageal achalasia: outcomes } \\
\text { of the first } 100 \text { patients with } \\
\text { short-term follow-up }\end{array}$ & 99 & 12 & Esophagus & Original research \\
\hline 7 & Terheggen G & Gut 2017;66:783-793 & $\begin{array}{l}\text { A randomised trial of endoscopic } \\
\text { submucosal dissection versus } \\
\text { endoscopic mucosal resection } \\
\text { for early Barrett's neoplasia }\end{array}$ & 90 & 12 & Esophagus & Original research \\
\hline 8 & $\begin{array}{l}\text { ASGE } \\
\text { Technology } \\
\text { Committee; } \\
\text { Maple JT }\end{array}$ & $\begin{array}{l}\text { Gastrointest Endosc } \\
2015 ; 81: 1311-1325\end{array}$ & $\begin{array}{l}\text { Endoscopic submucosal } \\
\text { dissection }\end{array}$ & 83 & 18 & All & Review \\
\hline 8 & Chevaux JB & $\begin{array}{l}\text { Endoscopy } \\
\text { 2015;47:103-112 }\end{array}$ & $\begin{array}{l}\text { Clinical outcome in patients } \\
\text { treated with endoscopic } \\
\text { submucosal dissection for } \\
\text { superficial Barrett's neoplasia }\end{array}$ & 83 & 24 & Esophagus & Original research \\
\hline 10 & Hiki N & $\begin{array}{l}\text { Dig Endosc } \\
\text { 2015;27:197-204 }\end{array}$ & $\begin{array}{l}\text { Laparoscopic endoscopic } \\
\text { cooperative surgery }\end{array}$ & 66 & 20 & Stomach & Review \\
\hline
\end{tabular}

PMC, PubMed Central; JGES, Japan Gastroenterological Endoscopy Society; EMR, endoscopic mucosal resection. 
Supplementary Table 3. Journals of the Top 50 Most-cited Articles of Google Scholar Bibliometrics in Endoscopic Submucosal Dissection Research Published after 2015 among the Top 1,000 Most-cited Articles

\begin{tabular}{|c|c|c|c|c|c|}
\hline Rank & Journal & $\begin{array}{l}\text { Number of published articles } \\
\text { in each journal among the } \\
\text { top-50 cited articles }\end{array}$ & $\begin{array}{c}\text { Journal impact fac- } \\
\text { tor based on JCR } \\
2017\end{array}$ & Eigenfactor $^{\mathrm{TM}}$ score & Category by JCR \\
\hline 1 & Endoscopy & 10 & 6.629 & 0.018 & $\begin{array}{l}\text { Gastroenterology \& } \\
\text { hepatology/surgery }\end{array}$ \\
\hline 2 & Gastrointestinal Endoscopy & 9 & 7.204 & 0.034 & $\begin{array}{l}\text { Gastroenterology \& } \\
\text { hepatology }\end{array}$ \\
\hline 3 & Digestive Endoscopy & 5 & 3.375 & 0.005 & $\begin{array}{l}\text { Gastroenterology \& } \\
\text { hepatology/surgery }\end{array}$ \\
\hline 4 & Gastric Cancer & 4 & 5.045 & 0.007 & $\begin{array}{l}\text { Gastroenterology \& } \\
\text { hepatology/oncology }\end{array}$ \\
\hline 4 & $\begin{array}{l}\text { Surgical Endoscopy and } \\
\text { Other Interventional } \\
\text { Techniques }\end{array}$ & 4 & 3.117 & 0.042 & Surgery \\
\hline 6 & $\begin{array}{l}\text { American Journal of } \\
\text { Gastroenterology }\end{array}$ & 2 & 10.231 & 0.056 & $\begin{array}{l}\text { Gastroenterology \& } \\
\text { hepatology }\end{array}$ \\
\hline 6 & Digestion & 2 & 2.037 & 0.003 & $\begin{array}{l}\text { Gastroenterology \& } \\
\text { hepatology }\end{array}$ \\
\hline 6 & $\begin{array}{l}\text { Endoscopy International } \\
\text { Open }\end{array}$ & 2 & Not available & Not available & Not available \\
\hline 6 & Gut & 2 & 17.016 & 0.065 & $\begin{array}{l}\text { Gastroenterology \& } \\
\text { hepatology }\end{array}$ \\
\hline
\end{tabular}

JCR, journal citation reports. 
Supplementary Table 4. The Top 10 AAS Articles in Endoscopic Submucosal Dissection Research (2006-2019)

\begin{tabular}{|c|c|c|c|c|c|c|c|}
\hline Rank & First author & Journal & Title & AAS & $\begin{array}{l}\text { Citation } \\
\text { counts } \\
(\mathrm{PMC})\end{array}$ & $\begin{array}{l}\text { Stomach vs. } \\
\text { colon vs. } \\
\text { esophagus } \\
\text { vs. } \\
\text { duodenum } \\
\end{array}$ & Type of article \\
\hline 1 & Hahn KY & $\begin{array}{l}\text { Surg Endosc } \\
\text { 2018;32:73-86 }\end{array}$ & $\begin{array}{l}\text { Comparative study between endoscopic } \\
\text { submucosal dissection and surgery in pa- } \\
\text { tients with early gastric cancer }\end{array}$ & 21 & 0 & Stomach & Original research \\
\hline 2 & Fuccio L & $\begin{array}{l}\text { Gut } \\
\text { 2018;67:1464-1474 }\end{array}$ & $\begin{array}{l}\text { Why attempt en bloc resection of non-pe- } \\
\text { dunculated colorectal adenomas? A sys- } \\
\text { tematic review of the prevalence of super- } \\
\text { ficial submucosal invasive cancer after } \\
\text { endoscopic submucosal dissection }\end{array}$ & 20 & 3 & Colon & $\begin{array}{l}\text { Original research } \\
\text { (systematic re- } \\
\text { view/meta-analy- } \\
\text { sis) }\end{array}$ \\
\hline 3 & Li Y & $\begin{array}{l}\text { Endoscopy } \\
\text { 2018;50:886-890 }\end{array}$ & $\begin{array}{l}\text { Endoscopic mucosa-sparing lateral dis- } \\
\text { section for treatment of gastric sub- } \\
\text { mucosal tumors: a prospective cohort } \\
\text { study }\end{array}$ & 18 & 0 & Stomach & Original research \\
\hline 4 & Backes Y & $\begin{array}{l}\text { BMC Gastroenterol } \\
\text { 2016;16:56 }\end{array}$ & $\begin{array}{l}\text { Endoscopic mucosal resection (EMR) ver- } \\
\text { sus endoscopic submucosal dissection } \\
\text { (ESD) for resection of large distal non-pe- } \\
\text { dunculated colorectal adenomas } \\
\text { (MATILDA-trial): rationale and design } \\
\text { of a multicenter randomized clinical trial }\end{array}$ & 15 & 7 & Colon & Original research \\
\hline 4 & $\begin{array}{l}\text { Subramaniam } \\
\text { S }\end{array}$ & $\begin{array}{c}\text { Gastrointest Endosc } \\
\text { 2017;86:608-618 }\end{array}$ & $\begin{array}{l}\text { Complex early Barrett's neoplasia at } 3 \\
\text { Western centers: European Barrett's } \\
\text { Endoscopic Submucosal Dissection Trial } \\
\text { (E-BEST) }\end{array}$ & 15 & 3 & Esophagus & Original research \\
\hline 6 & Qi ZP & $\begin{array}{l}\text { Gastrointest Endosc } \\
\text { 2018;87:540-548.e1 }\end{array}$ & $\begin{array}{l}\text { Efficacy and safety of endoscopic sub- } \\
\text { mucosal dissection for submucosal tu- } \\
\text { mors of the colon and rectum }\end{array}$ & 13 & 0 & Colon & Original research \\
\hline 6 & Kinoshita S & $\begin{array}{l}\text { Gastrointest Endosc } \\
\text { 2018;87:1079-1084 }\end{array}$ & $\begin{array}{l}\text { The role of colorectal endoscopic sub- } \\
\text { mucosal dissection in patients with ulcer- } \\
\text { ative colitis }\end{array}$ & 13 & 1 & Colon & Original research \\
\hline 6 & Emura $\mathrm{F}$ & $\begin{array}{c}\text { Gastrointest Endosc } \\
\text { 2015;82:804-811 }\end{array}$ & $\begin{array}{l}\text { Therapeutic outcomes of endoscopic sub- } \\
\text { mucosal dissection of differentiated early } \\
\text { gastric cancer in a Western endoscopy set- } \\
\text { ting (with video) }\end{array}$ & 13 & 6 & Stomach & Original research \\
\hline 9 & Milano RV & $\begin{array}{l}\text { Surg Endosc } \\
\text { 2018;32:2328-2339 }\end{array}$ & $\begin{array}{l}\text { Resection outcomes and recurrence rates } \\
\text { of endoscopic submucosal dissection } \\
\text { (ESD) and hybrid ESD for colorectal tu- } \\
\text { mors in a single Italian center }\end{array}$ & 12 & 0 & Colon & Original research \\
\hline 10 & Liao Z & $\begin{array}{l}\text { Gastrointest Endosc } \\
\text { 2018;88:543-546 }\end{array}$ & $\begin{array}{l}\text { Transplantation of autologous esophageal } \\
\text { mucosa to prevent stricture after circum- } \\
\text { ferential endoscopic submucosal dis- } \\
\text { section of early esophageal cancer (with } \\
\text { video) }\end{array}$ & 11 & 0 & Esophagus & Original research \\
\hline 10 & Saunders BP & $\begin{array}{l}\text { Nat Rev } \\
\text { Gastroenterol } \\
\text { Hepatol } \\
\text { 2016;13:486-496 }\end{array}$ & $\begin{array}{l}\text { Endoscopic mucosal resection and endo- } \\
\text { scopic submucosal dissection of large co- } \\
\text { lonic polyps }\end{array}$ & 11 & 4 & Colon & Review \\
\hline
\end{tabular}

AAS, Altmetric Attention Score; PMC, PubMed Central. 
Supplementary Table 5. Journals with Two or More of the Top 50 AAS Articles in Endoscopic Submucosal Dissection Research

\begin{tabular}{llcccc}
\hline Rank & Journal & $\begin{array}{c}\text { Number of published articles } \\
\text { in each journal among the } \\
\text { top-50 AAS articles }\end{array}$ & $\begin{array}{c}\text { Journal impact fac- } \\
\text { tor based on JCR } \\
2017\end{array}$ & Eigenfactor ${ }^{\mathrm{TM}}$ score & Category by JCR \\
\hline 1 & Gastrointestinal Endoscopy & 26 & 7.204 & 0.034 & $\begin{array}{c}\text { Gastroenterology \& } \\
\text { hepatology }\end{array}$ \\
2 & VideoGIE & 18 & Not available & Not available & Not available \\
3 & $\begin{array}{l}\text { Surgical Endoscopy and Other } \\
\text { Interventional Techniques }\end{array}$ & 4 & 3.117 & 0.042 & Surgery \\
4 & Medicine & 2 & 2.028 & 0.008 & $\begin{array}{c}\text { Medicine, general \& } \\
\text { internal }\end{array}$ \\
\hline
\end{tabular}

AAS, Altmetric Attention Score; JCR, journal citation reports. 
Supplementary Table 6. Influential Words in Title among the Top 500 Most-cited Articles in Web of Science Core Collection

\begin{tabular}{|c|c|}
\hline Term & Relevance-score \\
\hline Colorectal ESD EMR & 3.89 \\
\hline Gastric ESD & 3.89 \\
\hline STD & 3.89 \\
\hline Guideline & 3.89 \\
\hline Novel submucosal gel & 3.89 \\
\hline Radiofrequency ablation & 3.89 \\
\hline Simultaneous ESD & 3.89 \\
\hline Synchronous double EGCs & 3.89 \\
\hline Large early esophageal squamous cell neoplasia & 3.89 \\
\hline Ulcerative EGC & 3.89 \\
\hline Accurate diagnosis & 3.16 \\
\hline Assessment & 3.16 \\
\hline Circumferential superficial esophageal neoplasm & 3.16 \\
\hline Colectomy & 3.16 \\
\hline Competence level & 3.16 \\
\hline Double tunnel & 3.16 \\
\hline Endoscopic band ligation & 3.16 \\
\hline Esophageal circumferential en bloc ESD & 3.16 \\
\hline Giant polyp & 3.16 \\
\hline Hemospray & 3.16 \\
\hline Injectable hydrogel & 3.16 \\
\hline Laparoscopic resection & 3.16 \\
\hline Multifocal bleeding & 3.16 \\
\hline Rectal ESD & 3.16 \\
\hline Retraction problem & 3.16 \\
\hline Short term outcomes & 3.16 \\
\hline New technique & 3.16 \\
\hline Perioperative advantage & 3.16 \\
\hline Safe & 3.16 \\
\hline Small gastric stromal tumor & 3.16 \\
\hline Trainee & 3.16 \\
\hline Learning curve & 3.16 \\
\hline Ultra-low rectal ESD & 3.16 \\
\hline
\end{tabular}

VOSviewer calculates a relevance-score for each noun phrase. Noun phrases have a low relevance-score if their co-occurrences with other noun phrases follow a relatively random pattern; alternatively, they have high relevance-scores if they co-occur mainly with a limited set of other noun phrases. Noun phrases with low relevance-scores tend to be quite general, while noun phrases with high relevance-scores typically have more specific meanings. ${ }^{13}$

ESD, endoscopic submucosal dissection; EMR, endoscopic mucosal resection; STD, submucosal tunnel dissection; EGC, early gastric cancer. 
Supplementary Table 7. Influential Words in Abstract among the Top 500 Most-cited Articles in Web of Science Core Collection

\begin{tabular}{|c|c|}
\hline Term & Relevance-score \\
\hline Adhesive material & 2.88 \\
\hline Advanced endoscopic treatment & 2.88 \\
\hline Cell sheet technology & 2.88 \\
\hline Cultured autologous oral mucosal epithelial cell sheet & 2.88 \\
\hline Endoscopic transplantation & 2.88 \\
\hline Epithelialization & 2.88 \\
\hline Esophageal ulcer & 2.88 \\
\hline Key technology & 2.88 \\
\hline Oral mucosal tissue & 2.88 \\
\hline Regenerative procedure & 2.88 \\
\hline Wound site & 2.88 \\
\hline Protein expression level & 2.88 \\
\hline Direct gene expression level & 2.84 \\
\hline Luciferase assay & 2.84 \\
\hline Molecular mechanism & 2.84 \\
\hline mRNA & 2.84 \\
\hline Pathway & 2.84 \\
\hline Biomarker & 2.84 \\
\hline Real time PCR & 2.84 \\
\hline Recurrence free rate & 2.84 \\
\hline Seed sequence & 2.84 \\
\hline 3'-UTR & 2.84 \\
\hline Target gene & 2.84 \\
\hline Viability & 2.84 \\
\hline Western blot analysis & 2.84 \\
\hline
\end{tabular}

PCR, polymerase chain reaction; UTR, untranslated region. 
Supplementary Table 8. Influential Words in Title and Abstract among the Top 500 Most-cited Articles in Web of Science Core Collection

\begin{tabular}{|c|c|}
\hline Term & Relevance-score \\
\hline Gastric ESD & 13.85 \\
\hline Novel submucosal gel & 13.85 \\
\hline Hemospray & 12.20 \\
\hline Multifocal bleeding & 12.20 \\
\hline Ultra-low rectal ESD & 12.20 \\
\hline Seed sequence & 11.50 \\
\hline Guideline & 11.50 \\
\hline Complete endoscopic closure & 7.53 \\
\hline Endoloop & 7.53 \\
\hline Large gastric defect & 7.53 \\
\hline Esophagus localized recurrence & 7.51 \\
\hline Definitive chemoradiotherapy & 7.51 \\
\hline Esophageal squamous cell cancer & 7.51 \\
\hline Circumferential superficial esophageal neoplasm & 6.97 \\
\hline Double tunnel & 6.97 \\
\hline Recanalization & 6.67 \\
\hline Complete postradiation esophageal obstruction & 6.67 \\
\hline Gastroparesis & 6.46 \\
\hline Surgical vagal lesion & 6.46 \\
\hline Endoscopic pyloromyotomy & 6.46 \\
\hline Gastric STD & 6.46 \\
\hline Rectal ESD & 5.68 \\
\hline Retraction problem & 5.68 \\
\hline Novel traction method & 3.99 \\
\hline Nylon string & 3.99 \\
\hline Steroid gel application & 3.81 \\
\hline Post ESD ulcer & 3.64 \\
\hline Scope clip system & 3.64 \\
\hline Endoscopic vessel sealing & 2.94 \\
\hline Novel endoscopic precoagulation technique & 2.94 \\
\hline
\end{tabular}

ESD, endoscopic submucosal dissection; STD, submucosal tunnel dissection. 